\title{
PENGARUH INTENSITAS BIMBINGAN ORANG TUA DAN SARANA PRASARANA TERHADAP MOTIVASI BELAJAR SISWA SERTA IMPLIKASINYA PADA PRESTASI BELAJAR SISWA (SURVEI PADA MATA PELAJARAN KEWIRAUSAHAAN DI SMK ULIL ALBAB DEPOK KABUPATEN CIREBON)
}

${ }^{1}$ Mokhammad Wahyudin

${ }^{1}$ STAIMA CIREBON

Email: mokhammad wahyudin@yahoo.com

\begin{abstract}
The purpose of this study was to determine the effect of the intensity of parental guidance and infrastructure to the students' motivation and their implications for student achievement Smk Ulil Albab Cirebon Depok. The purpose of this study are: 1) To find a picture of student achievement, the intensity of parental guidance, facilities and students' motivation to learn; 2) To determine the effect intensity of parental guidance and infrastructure to student motivation and its implications on learning achievement. The method used is descriptive survey method verification. Data collected through questionnaires. In this study were used as the student population is Smk Ulil Albab Cirebon Depok many as 1556 people. The sample was 318 people. By using a sampling technique that is proportional random sampling. Based on the calculation and analysis of data, it can be concluded that: 1) Overview of learning achievement Students medium category, the intensity of parental guidance category is, the infrastructure category is, and student motivation sedang.2 category) there is a positive influence on the intensity of parental guidance and infrastructure on the students motivation. 3) There is no positive effect of the intensity of parental guidance on motivation to learn. 4) There is a positive effect of infrastructure study on motivation to learn. 5) There is no positive effect of the intensity of parental guidance, infrastructure and learning motivation on learning achievement. 6) There is no positive effect of the intensity of parental guidance on learning achievement. 7) There is no positive effect of infrastructure on student achievement. 8) There is no positive effect of learning motivation on student achievement.
\end{abstract}

Keywords: Parental Guidance intensity, Infrastructure, Motivation, Learning achievement.

\section{ABSTRAK}

Tujuan dari penelitian ini adalah untuk mengetahui pengaruh intensitas bimbingan orang tua dan prasarana terhadap motivasi belajar siswa dan implikasinya terhadap prestasi belajar siswa Smk Ulil Albab Cirebon Depok. Tujuan dari penelitian ini adalah: 1) Menemukan gambaran prestasi belajar siswa, intensitas bimbingan orang tua, sarana dan prasarana terhadap motivasi belajar siswa; 2) Untuk mengetahui intensitas pengaruh bimbingan orang tua dan sarana prasarana terhadap motivasi belajar siswa dan implikasinya terhadap prestasi belajar. Metode yang digunakan adalah metode deskriptif. Data dikumpulkan melalui kuesioner. Dalam penelitian ini digunakan sebagai populasi siswa Smk Ulil Albab Cirebon Depok sebanyak 1556 orang. Sampelnya 318 orang. Dengan menggunakan teknik pengambilan sampel yaitu proportional random sampling. Berdasarkan hasil perhitungan dan analisis data, dapat disimpulkan bahwa: 1) Gambaran prestasi belajar siswa kategori sedang, intensitas kategori bimbingan orang tua adalah, kategori sarana prasara, dan motivasi belajar siswa kategori sedang. 2) ada pengaruh positif intensitas bimbingan orang tua dan sarana prasarana terhadap motivasi siswa. 3) Tidak ada pengaruh positif dari intensitas bimbingan orang tua terhadap motivasi belajar. 4) Ada pengaruh positif dari sarana prasarana terhadap motivasi belajar. 5) Tidak ada pengaruh positif dari intensitas bimbingan orang tua, sarana prasarana dan motivasi belajar 
terhadap prestasi belajar. 6) Tidak ada pengaruh positif dari intensitas bimbingan orang tua terhadap prestasi belajar. 7) Tidak ada pengaruh positif dari sarana prasarana terhadap prestasi belajar siswa. 8) Tidak ada pengaruh positif motivasi belajar terhadap prestasi belajar siswa.

Kata kunci: Intensitas Bimbingan Orang Tua, Prasarana, Motivasi, Prestasi Belajar.

\section{PENDAHULUAN}

Perkembangan jaman semakin modern terutama pada era globalisasi pada masa sekarang ini yang menuntut adanya sumber daya manusia yang memilki kualitas tinggi. Peningkatan sumber daya manusia merupakan prasyarat yang mutlak untuk mencapai suatu pembangunan. Salah satu wadah untuk meningkatkan kualitas sumber daya manusia tersebut adalah pendidikan.

Pendidikan merupakan salah satu proses dalam pembangunan manusia untuk mengembangkan dirinya agar dapat menghadapi segala permasalahan yang timbul pada diri manusia. Hal ini berarti pendidikan merupakan salah satu masalah yang ada hubungannya dengan perkembangan dan kemajuan suatu bangsa, sehingga pendidikan harus menghasilkan perubahan dan dapat mengembangkan kehidupan bangsa. Keberhasilan program harus dapat membantu tercapainya tujuan pendidikan nasional, sehingga akan didapatkan generasi yang dapat memajukan kehidupan bangsa yang sesuai dengan bidangnya masing-masing.

Sekolah Menengah Kejuruan (SMK) mempunyai tujuan yaitu menciptakan atau menyiapkan siswa agar siswa mempunyai kemampuan untuk melanjutkan ke jenjang pendidikan yang lebih tinggi yaitu ke perguruan tinggi atau bisa berwirausaha karena sudah dibekali keahlian lain. Salah satu usaha yang digunakan untuk mewujudkan kemampuan yaitu dengan meningkatkan prestasi belajar siswa.

Prestasi belajar merupakan tolak ukur yang pertama untuk mengetahui tingkat keberhasilan seseorang. Oleh karena itu, prestasi yang tinggi dapat dikatakan bahwa ia telah berhasil dalam pembelajaran. Prestasi belajar siswa dapat dipengaruhi oleh beberapa faktor baik dari diri siswa (faktor intern), maupun dari luar siswa (faktor ekstern).

Proses belajar mengajar semakin meminta perhatian di kalangan peminat dan ahli IImu Pendidikan dan Keguruan sedangkan model dan media pembelajaran yang menjadi pengaruh hasil belajar siswa, banyak faktor-faktor lain yang menjadi pendukung tumbuhnya hasil belajar siswa baik faktor intern maupun faktor ekstern dari siswa tersebut. Dari setiap proses belajar atau kegiatan pembelajaran yang dilakukan, tentunya setiap siswa menginginkan nilai atau hasil yang baik.

\section{LANDASAN TEORI}

\section{Belajar dan Pembelajaran}

Belajar merupakan kegiatan yang tidak dapat dipisahkan dari kehidupan individu, setiap individu pernah mengalami proses belajar. Proses belajar bisa dilakukan secara formal maupun tidak formal. Secara formal diperoleh dari lembaga-lembaga formal seperti sekolah, sedangkan tidak formal dapat diperoleh dari pengalaman dalam kehidupan seharihari. Belajar tidak ada batasan, waktu, usia, jenis kelamin, tempat, semuanya tidak menjadi batasan dalam melakukan kegiatan belajar. Belajar sangat penting dalam kehidupan individu, melalui belajar dapat terjadi perubahan pengetahuan baik secara sempit atau luas. Dengan belajar seseorang yang sebelumnya tidak mengetahui suatu hal menjadi tahu.

Menurut Skinner (2009: 9), "Belajar adalah suatu perilaku. Pada saat orang belajar, maka responsnya menjadi lebih baik. Sebaliknya, bila ia tidak belajar maka responsnya menurun". 


\section{Pembelajaran}

Kegiatan belajar erat kaitannya dengan pembelajaran, belajar dan pembelajaran merupakan dua istilah yang berbeda tetapi memiliki keterkaitan satu sama lain. Belajar dan pembelajaran merupakan satu kesatuan. Seperti telah dipaparkan sebelumnya bahwa belajar adalah sebuah kegiatan yang dilakukan oleh individu yang menghasilkan perubahan.

Menurut Sagala (2006: 61), "Pembelajaran ialah membelajarkan siswa menggunakan asas pendidikan maupun teori belajar merupakan penentu utama keberhasilan pendidikan".

\section{Intensitas Bimbingan Orang Tua}

Secara tradisional, keluarga diartikan sebagi dua atau lebih orang yang dihubungkan dengan pertalian darah, perkawinan atau adopsi (hukum) yang memiliki tempat tinggal bersama. Sedangkan Morgan (1997) (dalam Sitorus, 1998:65) menyatakan bahwa keluarga merupakan suatu grup sosial primer yang didasarkan pada ikatan perkawinan (hubungan suami-istri) dan ikatan kekerabatan (hubungan antar generasi, orang tua-anak) sekaligus. Namun secara dinamis individu yang membentuk sebuah keluarga dapat digambarkan sebagai anggota dari grup masyarakat yang paling dasar tinggal bersama dan berinteraksi untuk memenuhi kebutuhan individu maupun antar individu mereka.

Bila ditinjau berdasarkan undang-undang No. 10 Tahun 1972 keluarga terdiri atas ayah, ibu, dan anak karena ikatan darah maupun hukum. Keluarga mengacu pada sekelompok individu yang berhubungan darah dan adopsi yang diturunkan dari nenek moyang yang sama.

Keluarga hubungannya dengan anak diidentifikasi sebagai tempat atau lembaga pengasuhan yang paling dapat member kasih sayang, kegiatan menyusui, efektif dan ekonomis. Di dalam keluargalah pertama kali anak-anak mendapat pengalaman diri langsung yang akan digunakan sebagai bekal hidupnya dikemudian hari melalui latihan fisik, sosial, mental, emosional dan spiritual. Karena anak ketika baru lahit tidak memiliki tata cara dan kebiasaan (budaya) yang begitu saja terjadi sendiri secara turuntemurun dari satu generasi ke generasi lain, oleh karena itu harus dikondisikan ke dalam suatu hubungan kebergantungan antara anak dengan orang tua dan anggota keluarga lain serta lingkungan yang mendukungnya baik dalam satu keluarga atau lingkungan masyarakat.

Bahkan seperti juga dikatakan oleh Malinowski (1930) (dalam Megawangi, 1998:66) tentang "principle of legitimacy" sebagai basis keluarga, bahwa struktur sosial (masyarakat) harus diinternalisasikan sejak individu dilahirkan agar seorang anak mengetahui dan memahami posisi dankedudukannya, dengan harapan agar mampu menyesuaikan dalam masyarakat kelak setelah ia dewasa. Dengan kata lain, keluarga merupakan sumber agen terpenting yang berfungsi meneruskan budaya melalui proses sosialisasi antara individu dengan lingkungan.

\section{Sarana dan Prasarana Belajar}

\section{Sarana Belajar}

Menurut Hafidz (2007: 65), "Sarana adalah peralatan dan perlengkapan yang secara langsung dipergunakan dan menunjang proses pendidikan, khususnya proses belajar mengajar, seperti gedung, ruang kelas, meja kursi, serta alat-alat dan media pengajaran".

Menurut Ibrahim Bafadal (2003: 2), "Sarana adalah semua perangkatan peralatan, bahan dan perabot yang secara langsung digunakan dalam proses pendidikan di sekolah".

Menurut Wahyuningrum (2004: 5), berpendapat bahwa sarana pendidikan adalah "Segala fasilitas yang diperlukan dalam proses pembelajaran, yang dapat meliputi barang bergerak maupun barang tidak bergerak agar tujuan pendidikan tercapai".

Dapat disimpulkan dari beberapa pendapat di atas, bahwa sarana belajar adalah segala fasilitas bisa berupa peralatan, bahan dan perabot yang langsung dipergunakan dalam proses belajar di sekolah. Tentunya semua prasarana dan sarana pendidikan harus dikelola dengan baik. 


\section{Prasarana Belajar}

Menurut Tim Dosen (2011: 51), "Prasarana adalah segala sesuatu yang erat kaitannya dengan kondisi tanah, bangunan dan perabotan yang menjadi penunjang terlaksananya proses pendidikan".

Menurut Hafidz (2007: 65), "Prasarana adalah fasilitas yang tidak langsung menunjang jalannya proses pendidikan atau pengajaran, seperti halaman, kebun, taman sekolah, jalan menuju sekolah, tetapi jika dimanfaatkan secara langsung untuk proses belajar mengajar, seperti taman sekolah".

Menurut Mulyasa (2006: 43), "Prasarana adalah sesuatu yang berkaitan dengan kriteria minimal tentang ruang belajar, tempat berolah raga, tempat beribadah, perpustakaan, laboratorium, bengkel kerja, serta sumber belajar lain, yang diperlukan untuk menunjang proses pembelajaran, termasuk penggunaan teknologi informasi dan komunikasi".

Dapat disimpulkan dari beberapa pendapat di atas, bahwa pengertian prasarana sangat erat kaitannya dengan kondisi tanah berkaitan dengan status kepemilikan tanah yang menjadi tempat pendidikan, bangunan berkaitan dengan kondisi gedung sekolah, ruangan kelas, tempat beribadah, perpustakaan, laboratorium, bengkel kerja, serta sumber belajar lain.

\section{Motivasi Belajar}

Istilah motivasi berasal dari kata motif yang dapat diartikan sebagai kekuatan yang terdapat dari dalam individu, yang menyebabkan individu tersebut bertindak atau berbuat. Hamzah B. Uno (2012: 9) mengatakan bahwa motivasi merupakan suatu dorongan yang timbul oleh adanya rangsangan dari dalam maupun dari luar sehingga seseorang berkeinginan untuk mengadakan perubahan tingkah laku atau aktifitas tertentu yang lebih baik dari sebelumnya.

Jadi di dalam proses belajar motivasi sangat diperlukan sebab seseorang yang tidak mempunyai motivasi dalam belajar akan terhambat untuk melakukan aktifitas belajar. Hal ini merupakan bukti bahwa sesuatu yang akan dikerjakan itu berpengaruh terhadap kebutuhannya. Seseorang yang mempunyai motivasi yang kuat dapat mencapai apa yang dia inginkan untuk menjadi suatu kebanggaan.

Pengertian motivasi menurut Sartain (dalam M. Ngalim Purwanto 2011: 60) mengatakan bahwa motivasi merupakan suatu peryataan yang kompleks di dalam suatu organisme yang mengarahkan tingkah laku terhadap suatu tujuan (goal) atau perangsang (incentive). Sedangkan Wahonosumidjo (dalam Hamzah B. Uno 2012: 8) mengatakan bahwa motivasi merupakan dorongan dan kekuatan dalam diri seseorang untuk melakukan tujuan tertentu yang ingin dicapainya. Sedangkan Hamalik (dalam Aunurrahman 2009: 114) motivasi adalah suatu perubahan energi di dalam pribadi seseorang yang ditandai dengan timbulnya efektif (perasaan dan reaksi untuk mencapai tujuan).

Berdasarkan pendapat para ahli di atas, menyimpulkan bahwa motivasi merupakan suatu dorongan atau kekuatan dari dalam diri maupun dari luar untuk melakukan suatu perubahan tingkah laku atau aktifitas yang lebih baik dari keadaan sebelumnya untuk mencapai tujuan tertentu.

Adanya motivasi dalam proses belajar akan membuat siswa lebih aktif untuk melakukan suatu pembelajaran. Sehingga siswa mampu berinteraksi di dalam proses belajar dan mampu meningkatkan prestasi belajar. Karena motivasi merupakan suatu penggerak yang dapat membangkitkan daya belajar seseorang agar lebih mudah menerima, memahami dan mengerti informasi yang telah diberikan guru.

Hipotetis merupakan anggapan dasar suatu yang dianggap benar untuk alasan pendapat meskipun kebenaranya masih harus dibuktikan. Menurut Heri Jauhari (2010: 39) hipotesis adalah dugaan sementara.

1. lintensitas bimbingan orang tua dan sarana prasara belajar berpengaruh positif terhadap motivasi belajar siswa. 
2. Intensitas bimbingan orang tua berpengaruh positif terhadap motivasi belajar siswa.

3. Sarana prasarana belajar berpengaruh positif terhadap motivasi belajar siswa.

4. Intensitas bimbingan orang tua, sarana prasara, dan motivasi belajar siswa berpengaruh positif terhadap prestasi belajar siswa.

5. Intensitas bimbingan orang tua berpengaruh positif terhadap prestasi belajar siswa.

6. Sarana prasarana belajar berpengaruh positif terhadap prestasi belajar siswa.

Motivasi belajar berpengaruh positif terhadap prestasi belajar.

\section{METODE PENELITIAN}

\section{Subjek Penelitian}

Dalam penelitian ini variable yang diteliti terdiri dari dua variable bebas (Independent Variabele), variabel antara (Variabele Intervening) dan variable terikat (Dependen Variabele). Variable bebas terdiri dari intensitas bimbingan orang tua $\left(\mathrm{X}_{1}\right)$, sarana prasarana $\left(X_{2}\right)$ dan variable moderator motivasi belajar siswa $\left(X_{3}\right)$, seadangkan variable terikatnya adalah prestasi belajar siswa (Y). Penelitian ini dilakukan di SMK Ulil Albab Depok Kabupaten Cirebon

\section{Metode Penelitian}

Berdasarkan permasalahan yang akan diteliti maka metode yang digunakan dalam penelitian ini adalah metode survei yang bersifat korelasional dan didukung dengan studi kepustakaan.

\section{Desain dan Jenis Penelitian}

Penelitian ini merupakan penelitian verifikatif yaitu penelitian yang bertujuan untuk menguji hubungan-hubungan variabel dari hipotesis-hipotesis yang diajukan disertai data empiris.

\section{Jenis dan Sumber Data}

Jenis data dalam penelitian ini terdiri dari data tentang karakteristik umum SMK Ulil Albab Depok Kab. Cirebon dan data tentang masing-masing variable dan sub variable yang dikaji. Sedangkan datanya yaitu (1) sumber data primer yaitu siswa SMK Ulil Albab Depok Kab. Cirebon, dan data sekunder yaitu data-data, dokumen. berikut:

Secara rinci jenis dan sumber data dalam penelitian ini disajikan pada table 3.2

Tabel 1

Jenis dan Sumber Data

\begin{tabular}{|l|l|}
\hline \multicolumn{1}{|c|}{ Ruang Lingkup Data } & \multicolumn{1}{c|}{ Sumber Data } \\
\hline Karakteristik umum & SMK Ulil Albab Depok Kab. Cirebon \\
\hline Gambaran prestasi belajar & $\begin{array}{l}\text { Siswa SMK Ulil Albab Depok Kab. } \\
\text { Cirebon yang menjadi responden }\end{array}$ \\
\hline $\begin{array}{l}\text { Gambaran intensitas bimbingan orang } \\
\text { tua }\end{array}$ & $\begin{array}{l}\text { Siswa SMK Ulil Albab Depok Kab. } \\
\text { Cirebon yang menjadi responden }\end{array}$ \\
\hline Gambaran sarana prasarana belajar & $\begin{array}{l}\text { Siswa SMK Ulil Albab Depok Kab. } \\
\text { Cirebon yang menjadi responden }\end{array}$ \\
\hline Gambaran motivasi belajar & $\begin{array}{l}\text { Siswa SMK Ulil Albab Depok Kab. } \\
\text { Cirebon yang menjadi responden }\end{array}$ \\
\hline
\end{tabular}




\section{Populasi, Sampel dan Teknik Sampling}

\section{Populasi}

Populasi dalam penelitian ini adalah seluruh siswa-siswi di SMK Ulil Albab Depok Kab. Cirebon tahun ajaran 2015 - 2016 yang berjumlah 1556 siswa. Berikut ini rincian populasi penelitian:

Tabel 2

Daftar Siswa Yang Menjadi Populasi Penelitian Tahun Pelajaran 2015/2016

\begin{tabular}{|c|c|c|}
\hline No. & Kelas & Jumlah Siswa \\
\hline 1. & Kelas X & 796 \\
\hline 2. & Kelas XI & 760 \\
\hline \multicolumn{2}{|c|}{ Jumlah Keseluruhan } & $\mathbf{1 5 5 6}$ \\
\hline
\end{tabular}

\section{Sampel}

Dalam penelitian ini tidak semua populasi diteliti, hal ini disebabkan oleh keterbatasan biaya, tenaga dan waktu. Berangkat dari keterbatasan tersebut, penulis bermaksud untuk mengambil sebagian populasi untuk dijadikan sampel. Sampel merupakan bagian populasi yang diteliti baik berupa orang maupun bukan orang. Ukuran sampel merupakan sekumpulan anggota dalam sampel yang karakteristiknya diteliti.

Adapun rumus yang digunakan untuk menentukan besarnya ukuran sampel yang akan diteliti adalah dengan menggunakan rumus Solvin seperti dikemukakan oleh Husein Umar (1997 : 74-75)sebagai berikut:

Keterangan:

$$
n=\frac{\mathrm{N}}{1+\mathrm{Ne}^{2}}
$$

$\mathrm{n}=$ Jumlah sampel

$\mathrm{N}=$ Jumlah populasi

$\mathrm{e}=$ Taraf kesalahan yang bias ditolerir

(tingkat kesalahan yang diambil dalam sampling ini sebesar $5 \%$ )

(Sumber : Husein Umar 2002:141)

Berdasarkan rumusan di atas maka jumlah sampel yang dijadikan sebagai penelitian berjumlah 318 orang siswa yang mana tergambar dalam perhitungan sebagai berikut:

$$
\begin{aligned}
& \mathrm{n}=\frac{1556}{1+(1556)(0,05)^{2}} \\
& \mathrm{n}=\frac{1556}{1+3,89} \\
& \mathrm{n}=\frac{1556}{4,89} \\
& \mathrm{n}=318,20=318
\end{aligned}
$$

Dengan menggunakan rumus tersebut maka ukuran sampel dalam penelitian ini adalah sebanyak 318 orang siswa SMK Ulil Albab Depok Kab. Cirebon dengan rincian sebagai berikut: 


\section{Tabel 3 \\ Rincian jumlah Sampel}

\begin{tabular}{|c|c|c|c|c|}
\hline No. & Kelas X & Sampel & Kelas XI & Sampel \\
\hline 1. & X Tsm 1 & 43 & XI Tsm 1 & 40 \\
\hline 2. & X Tsm 2 & 40 & XI Tsm 2 & 38 \\
\hline 3. & X Tsm 3 & 45 & XI Tsm 3 & 35 \\
\hline 4. & X Tsm 4 & 35 & XI Tsm 4 & 42 \\
\hline \multicolumn{2}{|c|}{ Jumlah Sampel } & $\mathbf{1 6 3}$ & Jumlah Sampel & $\mathbf{1 5 5}$ \\
\hline
\end{tabular}

\section{Teknik Sampling}

Teknik sampling merupakan teknik pengambilan sampel, untuk menentukan sampel yang digunakan dalam penelitian. Terdapat berbagai teknik sampling, dan yang digunakan dalam penelitian ini adalah teknik proportional random sampling.

\section{Alat Pengumpulan Data}

Angket (questionaire) Yaitu daftar pertanyaan yang diberikan kepada orang lain dan bersedia memberikan respon (responden) sesuai dengan permintaan pengguna.

\section{Uji Instrumen}

Langkah awal analisa data berupa menguji validitas dan reabilitas instrument. Uji validitas dan reliabilitas instrument dilakukan dengan tujuan untuk mengetahui apakah instrument tersebut layak untuk digunakan sebagai alat pengumpul data atau tidak.

\section{Uji Validitas}

Menurut Arikonto (2010: 212) menyatakan bahwa "Validitas adalah suatu ukuran yang menunjukan tingkat keandalan atau kesahihan suatu alat ukur".

\section{Uji Reliabilitas}

Selain pengujian validitas terhadap instrumen juga dilakukan pengujian reliabilitas. Uji reliabilitas adalah untuk mengkaji ketepatan hasil angket manakala angket tersebut diujikan kepada siswa yang sama lebih dari satu kali, atau dari perangkat angket yang setara kepada objek yang sama.

\section{Teknik Analisis Data}

Sebelum mengolah data, penulis memeriksa kelengkapan angket terlebih dahulu, untuk mengecek jumlah angket yang terkumpul kembali serta kelengkapan jawaban dari responden, kemudian dilakukan pengolahan terhadap data yang diperoleh dari intrumen angket dan menganalisisnya.

\section{Analisis Deskriptif}

Untuk mengetahui gambaran intensitas bimbingan orang tua, sarana prasarana, motivasi belajar terhadap prestasi belajar siswa di SMK Ulil Albab Depok Kab. Cirebon.

\section{Pengujian Persyaratan Analisis}

Data keempat variabel penelitian ini selanjutnya dianalisis dengan menggunakan analisis statistik inferensial melalui teknik regresi sederhana dan regresi ganda. Sebelum analisis data pengujian hipotesis terlebih dahulu dilakukan uji persyaratan analisis yakni uji normalitas dan uji multikolinieritas, uji heterokedastisitas dan uji auto korelasi.dengan menggunakan SPSS v.17 for windows. 


\section{Metode Analisis Data}

Dalam penelitian ini teknik yang diambil yaitu analisis jalur dikarenakan penelitian ini variabelnya lebih dari satu.

\section{Analisis Jalur (Path Analysis)}

Analisis jalur (path analysis) ini digunakan untuk memprediksi pengaruh variabel.

\section{PEMBAHASAN}

\section{Pengaruh Intensitas Bimbingan Orang Tua Dan Sarana Prasarana Terhadap Motivasi Belajar Siswa.}

Terdapat pengaruh positif intensitas bimbingan orang tua dan sarana prasarana terhadap motivasi belajar siswa. Hasil penelitian menunjukkan bahwa intensitas bimbingan orang tua dan sarana prasarana memiliki pengaruh $21,40 \%$ terhadap motivasi belajar.

Dengan kata lain bahwa pentingnya bimbingan orang tua dan sarana prasarana belajar dalam memberikan motivasi bagi anak atau siswa agar dalam proses pembelajaran siswa merasakan untuk termotivasi dengan adanya bimbingan orang tua dan sarana prasarana yang memadai.

\section{Pengaruh Intensitas Bimbingan Orang Tua Terhadap Motivasi Belajar Siswa}

Tidak terdapat pengaruh positif intensitas bimbingan orang tua terhadap motivasi belajar siswa. Hasil penelitian menunjukkan bahwa intensitas bimbingan orang tua memiliki pengaruh 0,0289\% terhadap motivasi belajar.

Walaupun penelitian yang dilakukan oleh peneliti sekarang intensitas bimbingan orang tua belum bias menunjukkan bahwa berpengaruh positif terhadap motivasi belajar siswa namun jangan dijadikan suatu pedoman untuk semua pihak dikarenakan dalam penelitian ini biasa terjadinya tidak berpengaruh positif terhadap motivasi belajar siswa dikarenakan banyak factor yang mempengaruhinya diantaranya banyak responden dalam penelitian ini yang memberikan keterangan terhadap peneliti bahwa orang tua jarang sekali membimbing anaknya dan bahkan tidak pernah membimbing anaknya dikarenakan orang tua mereka sangat sibuk dengan kesibukannya masing-masing yaitu salah satunya mencari nafkah baik itu mencari nafkah di luar negeri atau pun didalam negeri yang menyita waktunya hanya untuk mencari nafkah keluarganya.

Namun untuk itu, dalam proses pembelajaran motivasi merupakan salah satu aspek dinamis yang sangat penting. Seiring terjadinya siswa yang kurang berprestasi bukan disebabkan oleh kurangnya kemampuan. Tetapi disebabkan oleh kurangnya motivasi untuk belajar. Oleh karena itu, untuk memperoleh hasil belajar yang optimal, orang tua dituntut untuk dapat membimbing dan membangkitkan motivasi belajar siswa. Dengan demikian, sosok orang tua sangat berperan untuk kemajuan pendidikan.

\section{Pengaruh Sarana Prasarana Belajar Terhadap Motivasi Belajar Siswa}

Terdapat pengaruh positif sarana prasarana belajar terhadap motivasi belajar siswa. Hasil penelitian menunjukkan bahwa sarana prasarana belajar memiliki pengaruh $21,80 \%$ terhadap prestasi belajar.

Proses pembelajaran motivasi merupakan salah satu aspek dinamis yang sangat penting. Seiring terjadinya siswa yang kurang berprestasi bukan disebabkan oleh motivasi belajar. Tetapi disebabkan oleh kurangnya sarana prasarana untuk bisa memotivasi siswa untuk melakukan kegiatan belajar. Oleh karena itu, untuk memperoleh motivasi belajar yang lebih tinggi, guru dan orang tua dituntut untuk dapat membimbing dan membangkitkan motivasi belajar siswa. Dengan demikian, sosok guru dan orang tua sangat berperan untuk kemajuan pendidikan. 


\section{Pengaruh Intensitas Bimbingan Orang Tua, Sarana Prasarana dan Motivasi Belajar Terhadap Prestasi Belajar Siswa}

Tidak terdapat pengaruh positif intensitas bimbingan orang tua, sarana prasarana dan motivasi belajar siswa terhadap prestasi belajar siswa. Hasil penelitian menunjukkan bahwa Intensitas bimbingan orang tua, sarana prasarana dan motivasi belajar memiliki pengaruh $1,70 \%$ terhadap prestasi belajar.

Walaupun intensitas bimbingan orang tua, sarana prasrana, dan motivasi belajar belum bisa meningkatkan prestasi belajar siswa pada penelitian ini namun alangkah lebih baiknya pihak-pihak yang terkait bisa lebih meningkatkan dan menumbuhkan sikap dan tanggung jawabnya untuk bisa mengoptimalkan prestasi belajar siswa.

\section{Pengaruh Intensitas Bimbingan Orang Tua Terhadap Prestasi Belajar Siswa}

Tidak terdapat pengaruh positif intensitas bimbingan orang tua terhadap prestasi belajar siswa. Hasil penelitian menunjukkan bahwa intensitas bimbingan orang tua memiliki pengaruh $1,6129 \%$ terhadap prestasi belajar.

Namun dengan demikian peneliti memberikan anggapan bahwa pentingnya intensitas bimbingan orang tua yang diberikan oleh semua orang tua demi kepentingan anak-anaknya atau siswa dalam rangka untuk meningkatkan prestasi belajar siswa yang lebih maksimal.

\section{Pengaruh Sarana Prasarana Belajar Terhadap Prestasi Belajar Siswa}

Tidak terdapat pengaruh positif sarana prasarana belajar terhadap prestasi belajar siswa. Hasil penelitian menunjukkan bahwa sarana prasarana belajar memiliki pengaruh $1,6129 \%$ terhadap prestasi belajar.

Namun dengan demikian pentingnya peranan sarana prasarana belajar bagi siswa dalam belajar maka guru dan orang tua diharapkan dapat memberikan vasilitas mengenai sarana prasarana untuk kegiatan belajar siswa agar bisa meningkatkan prestasi belajar siswa yang lebih baik disekolahnya.

\section{Pengaruh Motivasi Belajar Terhadap Prestasi Belajar Siswa}

Tidak terdapat pengaruh positif motivasi belajar terhadap prestasi belajar siswa. Hasil penelitian menunjukkan bahwa motivasi belajar memiliki pengaruh $0,1521 \%$ terhadap prestasi belajar.

Namun mengingat pentingnya peranan motivasi bagi siswa dalam belajar maka guru diharapkan dapat membangkitkan dan meningkatkan motivasi belajar siswasiswanya. Agar siswa mencapai hasil belajar yang optimal maka siswa harus memiliki motivasi belajar yang tinggi. Namun pada kenyataannya, tidak semua siswa memiliki motivasi yang tinggi dalam belajar. Di sekolah tidak sedikit siswa yang memiliki motivasi belajar rendah perlu dilakukan suatu upaya dari guru agar siswa yang bersangkutan dapat meningkatkan motivasi belajarnya.

\section{PENUTUP:}

Berdasarkan uraian pembahasan penelitian yang telah dikemukakan pada bagian terdahulu, maka penulis ajukan beberapa rekomendasi sebagai berikut.

1. Karena prestasi belajar siswa masih dalam kategori sedang, sedangkan variabel yang diteliti hanya berpengaruh yakni intensitas bimbingan orang tua, sarana prasarana terhadap motivasi belajar siswa dan sarana prasarana terhadap motivasi belajar siswa namun bukan dijadikan suatu ukuran untuk diaplikasikan dikarenakan penelitian ini masih banyak faktor-faktor lain yang mempengaruhi dalam pelaksanaan penelitiannya. Maka penulis menghimbau untuk lebih ditingkatkan kembali menganai sarana prasarana dan motivasi belajar siswa agar prestasi belajar siswa bisa bertambah meningkat. 
2. Dalam rangka meningkatkan prestasi belajar siswa dan motivasi belajar siswa diharapkan peran orang tua di rumah dalam membimbing siswa atau anaknya lebih ditingkatkan. Orang tua diharapkan lebih maksimal meluangkan waktu untuk anakanaknya agar terjadi komunikasi dalam keluarga yang lebih efektif. Apabila kedua orang tua yang memiliki waktunya lebih banyak, maka diharapkan komunikasi yang dijalin lebih ditingkatkan kualitasnya agar motivasi dan prestasi belajar siswa meningkat.

3. Dalam rangka meningkatkan motivasi dan prestasi belajar siswa maka untuk lebih ditingkatkan lagi sarana prasarana dengan melengkapi dan memberikan sarana prasarana yang bermutu agar siswa bertambah motivasi belajarnya dan prestasi belajarnya pun akan meningkat.

4. Karena hasil penelitian belum menunjukan bahwa motivasi belajar siswa belum berpengaruh positif terhadap prestasi belajar siswa maka hendaknya para guru dan orang tua lebih memahami siswa atau anak didiknya mengenai latar belakang perilakunya, tujuan, harapan dan keinginanya sehingga motivasi belajarnya meningkat dan berkembang ke arah yang positif yakni meningkatkan prestasi belajar siswa.

Karena penelitian ini terbatas pada variabel intensitas bimbingan orang tua, sarana prasarana dan motivasi belajar serta belum menggunakan variabel lain yang mempengaruhi prestasi belajar siswa, maka perlu penelitian lebih lanjut yang mengungkap faktor-faktor lain yang mempengaruhi prestasi belajar siswa secara mendalam dengan cakupan penelitian yang lebih luas

\section{DAFTAR PUSTAKA}

Adi, Purnomo.2003.Lokakarya Fasilitas Olahraga.Jakarta:PT Gramedia Pustaka Utama

Al-Rasyid, Harun (1994), Teknik Pengambilan Sampel dan Penyusunan Skala, Program Studi IImu Sosial-Bidang Kajian Utama Sosiologi-Antropologi, Bandung, Program Pasca Sarjana Universitas Pajajaran.

Arikunto Suharsinih. (2010). Prosedur Penelitian. Jakarta : Rineka Cipta

Aunnurahman. (2009). Belajar Dan Pembelajaran. Bandung: Alfabeta.

Bafadal. I. (2009). Pengelolaan Perpustakaan Sekolah. Jakarta: Bumi Aksara.

Depdiknas, (2000), Manajemen Sekolah, Jakarta, Ditjen Dikdasmen.

Depdiknas, (2002). Kamus Besar Bahasa Indonesia Edisi Ketiga. Jakarta: Balai Pustaka.

Dimyati, Dkk. (2009). Belajar Dan Pembelajaran. Jakarta : Rineka Cipta.

Djamarah, B.S \& Aswan Zain (2010). Strategi Belajar Mengajar. Jakarta : Rineka Cipta.

Djiwandono, S.E.W, (2002), Psikologi Pendidikan, Jakarta, Grasindo.

Fatah, N, (2004), Ekonomi dan Pembiayaan Pendidikan, Bandung, Rosdakarya.

Hamzah B.Uno, (2007), Teori Motivasi dan Pengukurannya, Jakarta, Bumi Aksara.

Herabudin. (2009). Administrasi dan Supervisi pendidikan. Bandung: Pustaka Setia.

Isjana, (1993), Hubungan Konsep Diri dan Kebiasaan Belajar terhadap Prestasi Belajar, Jakarta, PTK IKIP.

Koentjoroningrat, (1983), Metode Penelitian Masyarakat, Jakarta, PT Gramedia.

Mulyasa. E. 2006. Kurikulum Yang Disempurnakan. Bandung: Remaja Krosda Karya.

Munadi. Y. (2008). Media Pembelajaran Sebuah pendekatan Baru. Jakarta: Gaung Persada Press.

Moh. Najir. 1988. Metode Penelitian. Jakarta: Ghalia Indonesia, h.64. 
Moh. Surya. (2004). Psikologi Pembelajaran dan Pengajaran. Bandung: Pustaka Alfabeta. Nazir, M. (1999), Metode Penelitian, Ghalia Indonesia.

Oemar, Hamalik (2000), Psikologi Belajar dan Mengajar, Bandung, Sinar Baru Algensinda. Prawiradilaga Salma Dewi. (2007). Prinsip Desain Pembelajaran. Jakarta:Kencana.

R. Ibrahim dan Nana Syaodih S. (2003). Perencanaan Pengajaran. Jakarta: Rineke Cipta. Riduwan. (2011). Dasar-Dasar Statistika. Bandung : Alfabeta.

Sagala, Syaiful. (2006). Konsep dan Makna Pembelajaran Untuk Membantu Memecahkan Problematika Belajar dan Mengajar. Bandung : CV Alfabeta.

Samsudin, (1990), Iklim Keluarga dalam Hubungannya dengan Perilaku Salah Asuh Siswa SMA di DIY, Tesis Magister tidak diterbitkan, IKIP Yogyakarta.

Sanjaya, W. (2010). Strategi Pembelajaran Berorientasi Standar Proses Pendidikan. Jakarta : Kencana Preneda Media Group.

Semiawan, C. (1987), Pendekatan Keterampilan Proses, Bagaimana Mengaktifkan Siswa dalam Mengajar, Jakarta, Gramedia.

Soeleman, MI. (2001), Pendidikan dalam Keluarga, Bandung, PT Alfabeta.

Slameto. (2003). Belajar dan Faktor-faktor Yang Mempengaruhinya. Jakarta: Rineka Cipta.

Sopiatin, Popi. (2010). Manajemen Belajar Berbasis Kepuasan Siswa.Bogor. Ghalia Indonesia.

Sudjana, N. (2010). Dasar-Dasar Proses Belajar Mengajar. Bandung: Sinar Baru Algensindo Offset.

Sudjana, N. (2006). Penilaian Hasil Belajar Proses Belajar Mengajar. Bandung: PT Remaja Rosdakarya Offset

Sugiyono. (2012). Metode Penelitian Pendidikan Pendekatan kuantitatif, Kualitatif, dan $R \& D$. Bandung : Alfabeta.

Sumanto, (2002). Pembahasan terpadu Statistika dan Metodologi Riset. Yogyakarta.

Sunarto, (Kamanto, (1998), Pengantar Sosiologi, Jakarta, Lembaga Penerbit FE Universitas Indonesia

Surakhmad, W. (1984), Pengantar Interaksi Belajar Mengajar : Dasar Teknik Metodologi Mengajar, Bandung, Tarsito.

Suryosubroto. (2002). Proses Belajar Mengajar Disekolah. Jakarta: Rineka Cipta.

Susilo Joko Muhammad. (2007). Kurikulum Tingkat Satuan Pendidikan. Yogyakarta: Pustaka Pelajar Offset.

Wahyusumidjo, (1992), Kepemimpinan Pendidikan dan Motivasi, Jakarta, Galia Indonesia.

Skripsi, Tesis, Artikel, Jurnal dan Sumber lainnya:

Ari Diaz, http://www.tribunkaltim.com

Amirin, M.T (2011). Pengertian Sarana dan Prasarana Pendidikan. Tatangmanguny. Wordspress. Com.

http://id.shvoong.com/writing-and-speaking/presenting/2106962-pengertian-sarana-danprasarana/\#ixzz2OjppCKAa

Kusmanto (2012). Pengaruh Kompetensi Pedagogik Guru dan Intensitas Bimbingan Orang Tua Terhadap Motivasi Belajar Dan Implikasinya Terhadap Prestasi Belajar Siswa. 
Survei Pada Siswa SMP Negeri se-Kecamatan Salem Kabupaten Brebes. Tesis pada Pascasarjana Universitas Kuningan: Tidak diterbitkan.

Lindawati, (2013). Pengaruh Sarana Dan Prasarana Terhadap Prestasi Belajar Siswa Pada Mata Pelajaran Ekonomi. Survey diMadrasah Aliyah Mafatihul Huda Kabupaten Cirebon Dan Smk Kandang Haur Indramayu. Skripsi pada FKIP Unswagati Cirebon: Tidak diterbitkan.

Mardi, (2010). Pengaruh Status Sosial Ekonomi Orang Tua Dan Motivasi Belajar Terhadap Prestasi Belajar Siswa Smp Negeri 2 Losari Kabupaten Brebes. Tesis pada Pascasarjana Universitas Kuningan. Tidak diterbitkan

Pengolahan data SPSS v. 17 terdapat di:

http//www.spssindonesia.com/2014/01/pengolahan data. 24 mei 2016. 21.15.

Rutesih, (2011). Pengaruh Status Ekonomi Keluarga Dan Intensitas Bimbingan Orang Tua Terhadap Perilaku Belajar Dan Implikasinya terhadap Hasil Belajar Siswa. Survei Pada Smp Negeri 1 Sukagumiwang Kabupaten Indramayu. Tesis pada Pascasarjana Universitas Kuningan: Tidak diterbitkan. 